\title{
SOCIOLOGICAL EFFECTS OF SPECIAL CONSUMPTION TAX REDUCTIONS: EMPIRICAL FINDINGS
}

\author{
Iinsan Cemil DEMiR ${ }^{1} \quad$ Ali BALKI ${ }^{2}$
}

\begin{abstract}
Taxes are used to perform many purposes, particularly to finance of public services. Especially in times of economic recession, States have gone to tax reductions to stimulate the economy. In the short term, the preferred policy tool to revive the aggregate demand is the reduction of taxes on consumptions. In this respect, during 2016-2018 periods, government reduced special consumption taxes in Turkey. The purpose of this study is to determine how individuals perceived and how they behaved after the recent special consumption tax reductions. For this purpose, a survey was conducted with 1304 people as a face to face and online manner. The general results of this survey are show that the applications of special consumption tax reductions are accepted appropriate and very useful.
\end{abstract}

Keywords: Tax Reductions, Special Consumption Tax, Sociological Effect, Tax Awareness.

JEL Code: H20, H30.

\section{Introduction}

Today, taxes are used as an important and effective fiscal policy tool in addition to financing public services. States try to reach the macro-economic indicators they target by using taxes as a means of intervention in the economy. For this purpose, taxes are actively used in combating inflation and deflation.

Various criteria are used to classify taxes. The most common classification in practice; classification according to the subject: income taxes, wealth taxes and taxes on spending. Special consumption taxes which are the subject of this study are located in the classification of taxes on expenditures. In the short term, taxes on expenditures as a fiscal policy instrument are mostly used in the fight against recession and deflation. Reductions in taxes on expenditures will stimulate effective domestic demand in the short term. Governments generally consider the impact of these reductions on macroeconomic indicators and budget while applying tax cuts. While these impacts are important, the sociological impacts of these discounts or the attitudes and behaviors of the society towards reductions are also important in achieving the targeted success.

In this study, primarily the conceptual framework is investigated; in the scope of review of the literature, empirical studies conducted so far regarding the special consumption tax in Turkey, the methods used, data sets and the results obtained were examined. Then, the special consumption tax reductions applied in our country in the period 2016 - 2018 and the reflections of these reductions on the budget were examined. In the last part, we presented and evaluated the results of the survey that we conducted on the sociological effects of special consumption tax reductions in Turkey.

\footnotetext{
1 Assoc. Prof., Afyon Kocatepe University, Faculty of Economics and Administrative Sciences, Department of Public Finance, icdemir@aku.edu.tr (corresponding author)

2 Lecturer, Afyon Kocatepe University, Dazkırı Vocational School, alibalki42@hotmail.com
} 


\section{Conceptual Framework}

In the production and distribution stages of the economic process, or in only one of them, against general consumption tax on all goods and services except for exceptions and exemptions, taxes on specific goods and services are called special consumption taxes. Special consumption taxes, which are more favorable than other forms of taxation to minimize the reaction to taxation, are one of the oldest taxes together with customs (Turhan, 1998: 165-166).

Special consumption tax practices vary from country to country, but can be divided into three groups according to the objectives and evaluation criteria (Due \& Friedlaender, 1981: 390-402):

- Special consumption taxes designed to improve efficiency in the use of resources (sumptuary excises);

- Special consumption taxes applied as the cost of utilizing public goods (excise taxes in lieu of charges);

- Governments frequently make some use of special consumption taxes for general revenue purposes (excises for general revenue).

In the international area, the harmonization of special consumption taxes by certain rules has been brought to the agenda for the first time in the member states of the European Union. The reason for the harmonization of special consumption taxes, the tax adverse effects in the free movement of goods in community member countries (Uzelturk, 2002: 383).

\section{Empirical Studies on Special Consumption Tax}

Since entry into force of the Special Consumption Tax Law in Turkey, most of the studies relating to excise duty are theoretical studies. The number of empirical studies is quite low.

Gergerlioglu \& Sumer (2015), in the survey conducted with 1,000 persons in Istanbul; according to the married, widows and bachelors; low-income individuals, according to individuals in other income groups; primary school graduates, according to other graduating categories; it was concluded that the spirits sale taxes further decreased the social costs caused by the consumption of spirits.

Demir et. al. (2017), in 46 different city provinces in Turkey they made a survey with 1813 taxpayers; in general, tax reductions are satisfied with the citizens, the economy is revitalized, tax revenues will not reduce and will not disrupt public services.

Sanver et. al. (2017), in the survey conducted with 345 persons in Istanbul, Kocaeli, Sakarya, Duzce and Bolu provinces; they have reached the conclusion that the special consumption tax reductions will not increase employment, the increase in special consumption tax from luxury car sales is not fair and that this leads to the purchase of second hand and lower cylinder volume cars for taxpayers and also the special consumption tax reduction that applied to the veterans and their relatives while buying cars is proper, but the removal of special consumption tax from the sale of boats and yachts is not fair.

Gergerlioglu (2017), in the survey conducted with 515 persons in Istanbul; it was concluded that compared to other age groups, those in the age range 25-39 are more affected from taxes on fuel consumption while participants who earn 773-1000 TL are more influenced from taxes on fuel consumption compared to other income groups. 


\section{Special Consumption Tax Reductions Applied in 2016 - 2018}

After the Special Consumption Tax Law came into force in Turkey, special consumption tax discounts were applied for various purposes, especially for revitalizing the economy.

To be implemented between the dates of 07.09.2016 - 30.06.2019 with the Law No. 6745; in order to renew the vehicles used in urban passenger transportation (taxi, minibus, bus, etc.) and commercial vehicles used in commercial cargo transportation, which are included in the list (II) attached to the Special Consumption Tax Law, the first acquisitions of the vehicles under the same tariff position order are excluded from the special consumption tax.

With the decision of the Council of Ministers No. 2017/9759 published in the Official Gazette dated 03.02.2017, the special consumption tax rate from yachts, boats and excursion ships in the list (II) attached to the Special Consumption Tax Law is 0\%. The rate of special consumption tax on air conditioning and some white goods listed in (IV) has been zeroized until 30.04.2017. This period was extended until 30.09.2017 by the Council of Ministers Decision No. 2017/10106, published in the Official Gazette on 29.04.2017.

According to the decision of the Council of Ministers no. 2018/11818 published in the Official Gazette dated 17.05.2018, depending on the increase in international oil prices and foreign exchange rates; gasoline, diesel, LPG and it is decided that the increases in the prices of some petroleum products will be met by deduction from the special consumption tax and will not be reflected in retail prices.

To be valid until 31.12.2018 with the President Decision no. 287 of the Official Gazette dated 31.10.2018; special consumption tax rates on the $250 \mathrm{cc}$ and below motorcycles listed in the list (II) attached to the Special Consumption Tax Law have been reduced to zero; on the other hand, white goods in list (IV) have been reduced to zero. The special consumption tax reductions were extended to 31.03.2019 with President Decisions of 535 and 540 published in the Official Gazette dated 31.12.2018. It was extended to 30.06.2019 with the President Decision of 843, published in the Official Gazette dated 21.03.2019.

\section{Methodology of Study and Empirical Findings}

The primary objective of the reduction applications made in expenditure taxes is to revitalize the economy by increasing the purchasing power of individuals. Therefore, the effect of tax reductions on macro-economic indicators is generally taken into consideration and the attitudes and behaviors of individuals against tax reductions are secondary. This study was conducted to measure the perceptions, attitudes and behaviors of individuals against the special consumption tax reductions applied in our country recently.

Study was conducted across Turkey with a total of 1304 people face to face and online survey.

\subsection{Empirical Findings}

The results of the survey conducted on special consumption tax reductions were subjected to OLS regression analysis. For this purpose, the mean of 3 survey expressions which were tested to be a factor, were taken and converted into a single variable. The mean of this factor is 3,74 . 
1- Special consumption tax reductions are required. (Strongly Disagree: 1, Strongly Agree: 5, Mean: 4,14)

2- Special consumption tax reductions are revitalized the economy. (Strongly Disagree: 1, Strongly Agree: 5, Mean: 3,94)

3- Special consumption tax reductions are reduced tax revenues. (Strongly Agree: 1 , Strongly Disagree: 5, Mean: 3,13)

\section{Regression analysis results can be summarized as follows:}

- Perception about special consumption tax reductions differ significantly from demographic variables only in terms of gender. Statistically; according to the results, men have more positive perception than women about special consumption tax reductions at $10 \%$ significance level.

- Those who consider tax as an unnecessary payment to the state (individuals with negative tax awareness) have a negative attitude towards special consumption tax reductions (5\% significance level).

- The level of satisfaction with special consumption tax reductions is higher for individuals with high level of awareness on special consumption tax than other individuals ( $10 \%$ significance level).

- Those who want to narrow the scope of the goods and services subject to the special consumption tax are more satisfied than the special consumption tax reductions compared to those who do not care (1\% significance level).

- The positive perception of those who want to end the practice of special consumption tax in Turkey is higher than other individuals ( $5 \%$ significance level).

- Those who think that the special consumption tax on oil and petroleum products is high, they are more positive for special consumption tax reductions than for those who think it is low (1\% significance level).

- Those who consider the special consumption tax from the goods harmful to human health as the cost of the health expenditures made to those who use these goods are generally negative towards the special consumption tax reductions (1\% significance level).

- Those who think that special consumption tax should not be taken over white goods, the satisfaction level of special consumption tax reductions is very high ( $1 \%$ significance level).

- Those who think that the special consumption tax has a direct impact on expenditures are positive against special consumption tax reductions (1\% significance level).

- Those who think that the special consumption tax on cars hinders the purchase of new cars is positively perceived against special consumption tax reductions ( $10 \%$ significance level).

- Cigarette etc. those who think that special consumption tax should be taken on the products that are addictive, they have a positive perception against special consumption tax reductions (5\% significance level). 


\section{Conclusion}

With the survey conducted with 1304 people in Turkey, attitudes and behaviors of individuals against the special consumption tax reduction has been measured. According to the results of the study; individuals generally have a positive attitude towards special consumption tax reductions; they think that the scope of the goods and services subject to special consumption tax should be narrowed and that the special consumption tax directly affects the expenditures they make. Moreover, the participation rate of individuals is quite high survey expressions which the ratio of special consumption tax taken on oil and petroleum products is high and the special consumption tax taken from cars prevents the purchase of new cars.

According to the results of OLS regression analysis performed with the data obtained from the study; the attitude towards special consumption tax reductions is significantly different according to gender. No significant difference was found in other demographic variables.

As a result, the recent special consumption tax reductions seem to be quite satisfactory from a sociological point of view, aside from macroeconomic targets. The fact that society cares about such reductions and planning of consumption expenditures taking into account reductions which indicate the density of individuals with rational expectations.

\section{References}

\section{Journal/Periodicals;}

Demir, i. C., Gokce, C. \& Cigerci, İ. (2017). "The Economic and Fiscal Effects of Tax Reductions: Recent Applications in Turkey", Research Journal of Politics, Economics and Management, 5 (5), pp. 75-88.

Gergerlioglu, U. (2017). "Analysis of the Behaviours and Attitudes towards Taxes Related to Automobile Fuel Consumption: Evidence from Istanbul", Erciyes University Journal of Faculty of Economics and Administrative Sciences, (49), pp. 59-86.

Gergerlioglu, U. \& Sumer, K. K. (2015). "Analysing of Mitigating Effects of Spirits Sale Taxes on Social Costs in terms of Individual Attitudes (Istanbul Province Case)", Sosyoekonomi, 23 (24), pp. 98-117.

Sanver, C., Ayas, I. \& Topalfakıoglu, N. M. (2017). "Reactions of Taxpayers to Changes in Special Consumption Tax", Adnan Menderes University Journal of Institute of Social Sciences, 4 (4), pp. 214-231.

\section{Books;}

Due, J. F. \& Friedlaender, A. F. (1981). Government Finance: Economics of the Public Sector, Seventh Edition, Ontario, Irwin-Dorsey Limited.

Turhan, S. (1998). Tax Theory and Policy, Istanbul, Filiz Bookstore.

\section{Papers;}

Uzelturk, H. (2002). "Special Consumption Taxes: Unending Reaction", 17. Public Finance Conference/Turkey, 22-25 May 2002, Mugla. 